\title{
失語症の症状と病変部位
}

\author{
—CT-scan による観察—— \\ 戸 塚 元 吉* 藤 林 真理子* \\ 船 井洋 光* 福 迫 陽子**
}

\section{The Relationship between the Type of Aphasia and the Location of the Lesion Observed by CT Scan}

\author{
Genkichi Totsuka, Mariko Fujibayashi, Hiroaki Funai \\ and Yoko Fukusako
}

The location and extent of the lesion in the brain was examined by computered tomography (CT) scan of 20 cases of various types of aphasia due to cerebral vascular accidents. Side view of the brain illustrating the location of the lesion was made from the horizontal tomograms of each case. The relationship between the type of aphasia and the location of the lesion was examined by superimposing each illustration upon another, and we obtained the following results :

1. Area covering the lesions of all the cases included the so called Broca's area, Wernicke's area and the area in between these two areas.

2. Aphasia of the non-fluent type had the tendency to have the lesion in the posterior and inferior part of the frontal lobe.

3 . In cases of the so called conduction type of aphasia, the lesion covered the area between the Broca's and the Wernicke's areas.

\section{I ・はじめに}

電子工学の進歩は脳実質の病変の診断に変革をもたら した. これまで大脳の器質的病変の診断には神経学的諸 検査のほか, 血管造影法, 気脳法, 脳波検查, 超音波診 断法，脳シンチグラフィーなどが用いられてきた. これ らの諸検査の結果を総合しても大脳病変の部位と範囲を 診断するにはなお十分でない，また検査に伴う侵襲もそ の適用をためらう一因であった.

1969年に英国の EMI 社において, Hausfield ら によ って製作された computered tomography, 別名 CT-scan

* 虎の門病院

** 東京都立養育院附属病院
は被検者の身体に負担を加えることなく脳実質の病変の 輪郭を正確に写すことのできる優れた装置である．脳血 管障害による軟巣化についても, この装置によれば病変 の部位と範囲を診断することができるようになった。

過去においては失語症の練別診断と予後の判定は主と して言語狱理学的所見から進められ, 脳病変のいかんは 参考になることが少なかった。脳病变と言語症状の対比 は，患者が死しした場合に剖検所見によって行われてき た. Broca, Wernicke の名が冠せられている言語中枢 の存在も剖検によって推定されたものである.

CT-scan の開発は言語治療を始める前に脳病变の部 位と範囲を診断することを可能にした。本研究は C T 所 見を言語治療に役立てる第一歩である.症例数について な拝十分とはいえないが，得られた知見の範囲でとりあ 
Vol. 18 No. 3 , 1977. 11

えず発表し，諸家の批判を仰ぎたい。

\section{II. 検査対象}

虎の門病院に来院した脳血管障害による失語聇患者 20 名を対象とした。これらの症例は詳細な言語病理学的款 断がなされて扣りまたた，CT-scan 上の病巣が局限的 で, 病巣の範囲を明確に知り得たものである。したがっ て本研究では失語症でも, 散在的な病変を示すもの, 脳 萎縮の著しいもの, 新鮮例, および脳腫瑒あるいは外傷 に起因するものは除外した.

各患者の言語症状は次に示すと㧍りであるが，その説 明に抢ける失語症のタイプ(群)の分類は, Schuell ら ${ }^{6)}$ の分類方法（表 1) 飞従った。 また，聞く，話す，読 む, 書く, 打よび計算の各能力について検査したが，そ の結果は各様式ごとに（）内の数字で示した。この 数字は障害の最も重い場合を 6 点とし, 障害が認められ ない場合を 0 点とする 7 段階評価を行って決めたもので ある.!

表 1 失語症の分類 (Schuell, 1964)

第 1 群 単純失語

聞く, 話す, 読む, 書くのすべての様式にわたって 言語機能の低下が認められるが, 視覚過程の障害, 感 覚運動過程の障害（構音失行）, マヒ性構音障害など を伴わない.

予後：すべての言語様式で良好な改善が期待でき る.

第 2 群 視覚障害性失語

第 1 群の障害に，視覚過程の障害を伴う。読み击き の機能がとくに著明に障害され，形の似た文字の混 同, 写字や書字に执ける上下左右の逆転などが認めら れる。

予後 : 聞き話す機能の回復は良好であるが，読み書 きの回復は遅れる。

第 3 群 感覚運動障害性失語（構音失行を伴う失語）

第 1 群の障害に, 感覚運動過程の障害（構音失行） を伴う．発語笳群のマヒはないが，語音を意図的に出 すことに障害がある。

予後 : 話寸機能の回復には限界があり, 進歩も遅い が，一応実用的機能を果たしうる程度まで達する。

第 4 群 散在病巣性失語

症状が広範囲にわたって散在し, 視覚過程の障害, マヒ性構音障害 (曣下困難と感情失禁とが共存する) などを伴う。

予後：患者の生理的执よび情緒的状態によって限定 される。

第 5 群 不可逆性失語（全失語） すべての言語様式にわたるほとんど完全な言語機能 の掊失が認められる。

Minor A 予後 : 機能的言語の回復は不能。

Minor B 部分的聴覚失認を伴う失語。

永続的なマヒ性構音障害を伴う軽い失語.
症例 1 日○谷已○蔵, 57 歳男, 発病後 6 力月, III群 (重).

聞く (4), 話す (6), 読む (4), 書く (5), 計算 (3).

自発語は,「アーアー」と声を発する程度で, ほとん ど火如. 発語失行が著明. 復唱, 音読も不可能. 聴覚的 理解, 読解は単語レベルのみある程度可能. 書字は困 難.

5 力月経過後, 単語の聴覚的理解と読解 (漢字) の改 善あり。訓練した漢字は書字可能.

症例 2 清 $\bigcirc$ 満 $\bigcirc, 46$ 歳男, 発病後19力月, 皿群(中). 聞く (1), 話す (3), 読む (2), 書く (4), 計算 (1).

発語は非流暢，会話時沿滞，探索行動，音韻変化あ り。短文を用いてからうじて意思表現可能. 聴覚的理 解, 読解は笑用的. 書字は単語では良好, 仮名単語, 文 は困難である。

$2 ， 3$ 力月経過後重度より中等度に改善，な䄳緩慢な 改善がみられる。

症例 3 高 $\bigcirc$ 徹 $\bigcirc, 47$ 嵅男, 発病後 2 週間, III群(軽). 聞く (1), 話す (1), 読む $(0)$, 書く (2), 計算 (2).

発語は非流暢．時折喚語困難あるも，だいたいは意思 表現可能. 聴覚理解, 読解ともに良好. 書字に少々誤り あり。

1 力月半訓練後, 文章の書字に改善あり.

症例 4 高 $\bigcirc$ 稔, 40 歳男, 発病後 7 年, III群 (軽).

聞く (1), 話す (1), 読む (1), 書く (1), 計算 (1).

発語は非流啺．言語のすべての様式にわたって軽度の 障害あり。

経過は全く変化なし。

症例 5 北○武 $\bigcirc, 45$ 瓷男, 発病後27力月, 伝導失語 (軽).

聞く (1), 話す (1), 読む (0), 書く (1), 計算 (0).

発語は流暢, ごく軽度に障害あり。復唱は 4 文節以上 の文が困難.

3 カ月訓練の後, 言語のすべての怺式に改善あり.

症例 6 大○信 $\bigcirc, 37$ 藏男, 発病後 14 力, 伝導失語 (重).

聞く (3), 話す (5), 読む (4), 書く (5), 計算 (2).

発語は流啺，喚語困難が著明なため, 簡単な内容を伝 えられるだけ。復唱は単語レベルはある程度可能だが, 文は困難. 聴覚理解, 読解は短文なら可能. 書字は漢字 
単語ならばかなりできるが，仮名は困難.

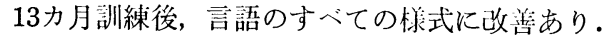

症例 7 岩 $\bigcirc$ 愛 $\bigcirc$ 蚛, 72 瓷男, 発病後 13 月, 伝導失 語 (重).

聞く（2）, 話す (3), 読む (4), 書く (4), 計算 (3).

発語は流暢，喚語困難に加えて著明な字性錯語あり。 また音節や音の転置に伴う自己修正が認められる。復 唱, 音読は困雉. 日常会話での理解は良好. 諳解は単語 は良好で，短文はある程度可能．書字は仮名 1 文字のみ 良好, 単語や文は困難.

7 カ月訓練後，改善あり。

症例 8 斎 $\bigcirc$ 春 $\bigcirc, 28$ 戍势, 発州後32力月, 伝導失語 (軽).

聞く（1）, 話す（2), 読む ( 2), 畵く (2), 計算 (2).

発語は流暢，喚語困難および復喝障害あり。その双方 に字性錯語がみられる．音節や音の轱狊を伴う自己修正 が認められる．恥覚理解は良好．長文の読解，書字は困 難.

6 力月半訓練後, 言語のすべての様式に收㾦あり.

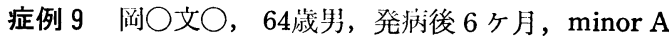
(軽).

聞く（2), 話す (1), 語む (1), 書く (1), 計算 (1).

発話は流暢．ときに喚語困難や字性鉷語あり．聴覚的 理解はわずかな聞き落し, 聞き誤りがある程度. 話すこ と, 読解, 書字は央用レベル。

2 力月半訓練後, 著明に收善, 特に書字, 計算能力が 変化した。

症例10 下○恒 $\bigcirc, 66$ 歳男, 発病後 2 力月, IV群十麻 瘏性構音障害.

聞く（4), 話す (4), 読む (5), 書く (6), 計算 (3).

発話は流暢，重度構音障害のため不明暸．喚語困難の ため簡単な内容しか表現できない。聴覚的理解は短文ま で, 読解, 書字ともに重篤な障害あり. 精神活動低下, 感情失禁あり.

3 カ月間訓練したが著变なし。

症例11 鈴 $\bigcirc$ 東 $\bigcirc$ 男, 70 瓷男, 発病後 1 力月, I 群 (軽).

聞く（1）, 話す (1), 諳む (1), 書く (1), 計算 (2).

発話は流暢。聞く, 話す, 読解に軽度障害。書字は短 文ならば可能。

症例12 安 $\bigcirc$ 英 $\bigcirc, 65$ 筬男, 発为後 1 力月, $V$ 群。
聞く（5), 話す（5)，読む（5)，書く（5)，計算 (5).

発話は流啺，すべての言語栐式にわたって重篤な障 害. 機能的な言語は残っているが，ときに簡単な文で質 問に答えることがある。

8 力月訓練後, 単語の聴覚認知と読解, 漢字単語の書 字はやや改扂あり。

症例13 永 $\bigcirc$ 哲 $\bigcirc, 46$ 筬男, 発病後 2 力月，超皮質性 運動失語に近い状態.

聞く（4), 話す (3), 読む (4), 書く（6), 計算 (4).

発話は流暢，復䎅，音読は良好。喚語困難と保続のた め, 簡単な会話のみかろらじて叮能. 聴覚的理解は短文 まで闭能．書字は仮名 1 文字のみ。

症例14 兼 $\bigcirc$ 喜 $\bigcirc, 60$ 琙男, 発病後 6 力月, $\mathrm{V}$ 群. 闻く（6), 話す (6), 誖む (6), 書く (6), 計算 (6).

「アーアー」と声を出すのみ，すべての言語面に重篤 な障害. 精神活動も低下.

症例15 山○一○，58筬男，発将後16年，I群（軽） 十ゲルストマン症候群.

聞く（2), 話す (1), 読む (2), 書く（5), 計算 (3).

発話は流暢. 聞く, 話す, 読解などの障害は軽度. 書 字は重篤な障害で熯字，仮名ともに困難．計算は加減の 及。

症例16 磯 $\bigcirc$ 高, 46藏男, 発病後 18 力（発作 3 回), I 群（中）十ゲルストマン証候群.

聞く（2), 話す (3), 読む (4), 書く (5), 計算 (5).

発話は汾暢・単語困難は著明だが，短文で意思表示叮 能. 復唱, 音読は単話レベルのみ. 聴覚的理解は良好. 書字, 計算に重篤な障害. 12力月間訓練後, 呼称, 単語 の書字に改善あり.

症例17 鈴 $\bigcirc$ 多 $\mathrm{N}, 58$ 筬男, 発病後 8 力月, I 群(軽) 十ゲルストマン泟候群.

聞く（1), 話す (1), 読む (2), 書く（3), 計算 ( 3 ).

発話は流暢.聞く, 話す, 読解などの障害は軽度，書 字は単語レベルで誤りめり。計算は加減は订能。乗除は 犃りあり。

症例18 入○輝 $\bigcirc, 48$ 冷男, 発病後 36 力, II群十麻 瘦性構音障害 (軽度).

闻く（1）, 話す (.1), 語む (4), 畫く（5), 計算 ( 3 ).

発話は流暢，音に柔みあり。読解は単語は可能，短文 
に䛊りあり。書字はからろじて単語のみ可能.

2 か月訓練後, 変化なし。

症例19 石 $\bigcirc$ 文 $\bigcirc, 44$ 歳女, 発病後26力月, I 群(軽). 聞く（1), 話す (1), 読む ( 1$)$, 書く (1), 計算 (2).

発話は流暢。すべての様式にわたって軽度の障害. 8 ケ月間訓練後, 寸べての様式にわたり改善あり. 症例20 嶋 $\bigcirc$ 綾 $\bigcirc, 12$ 歳女, 発病後 27 ケ月, 発語失行 (軽).

聞く（0), 話す ( 1$)$, 読む $(1)$, 書く ( 0$)$, 計算 (1).

発話は非流暢.ゆっくりだが，だいたい普通の会話が 可能.

10力月間訓練し，発語失行は著明に改善した。

さらに本研究では, 右利き, 右片麻㽻, 非失語症例を 3 例とりあげて対照群とした。

\section{III. 研究方法}

対象例には言語病理学的検査として S L T A， あるい は老研式失語症検査を適用した。検査結果に応じて, 次 の各群のいずれかに分類した。

1. III群（特に発話の非流暢に注目して）

2. 伝導失語群

3. I 群十書字障害

4 . 対照 (非失語) 群

CT-scan について，少しく詳述する.

CT-scan は病変を頭部断層像上に表現する．この画 像は頭部を輪切りにしたときの切断面をあらわしてい る.この輪切り面（断層面）を決めるためには，まず外 眼角と外耳道中心を結ぶ線を設定する．次にこの線に対 して $0 \sim 20^{\circ}$ の角度で前方を挙上した線を想定し, 左右 のこの線で決められる面を断層中心面とする．この面よ り $0.5 \mathrm{~cm}$ 下の平面を $\mathrm{A}$ 面， $0.5 \mathrm{~cm}$ 上の平面を $\mathrm{B}$ 面とし， $\mathrm{A}$ 面と $\mathrm{B}$ 面は同時に撮影できる．基準面より上方に $2 \mathrm{~cm}$ とに撮影を行らと， $1 \mathrm{~cm}$ ごとに断層写真が得られ，頭部 は 8〜10枚の断層像で表現される.

被検者は円筒形の “head box” に頭部を插入して仰卧 する、X線管とX線検出器が頭部の周囲で回転し，X線 管からは問欠的にX線ビームが発射される．頭部を通過 したX線は対側にある検出器に入り, 検出器からはX線 量に応じた電流がとり出される，1断買面を得るため に，方向の異なる照射が $256 \times 180$ 回行われる．その毎回 の検出電流から断層面上の $256 \times 2$ 点の X線吸収值が算 出される.この吸収值は発射線量/検出線量の対数で, 水を 0 ，空気を一 500 , 骨組織を約 500 としたときのそれ ぞれ相当する数值であらわされる。
断層面上の各点の吸収值はこれを数值として印字する こともできるが，通常は吸収值に比例した黑化度をもつ 点を配列した図形としてあらわされる。これがC T像で ある・

$\mathrm{C} \mathrm{T}$ 像において病変部分は健康な脳実質よりも $\mathrm{X}$ 線吸 収度が低く，淡く描かれ，“low density area”として 示される . 各断層面について “low density area”の輪 郭を定め，これに基づき，Schoultz の方法3゙にしたが って病変範囲を脳の側面図上に投影させた図を作成し た。頭の大きさは各人によって異なるので，此例計算を 行って，すべての患者が同じ大きさの頭をもっているも のとして補正した病変図を作った。

各患者の病変図を検討するとともに，全例（対照群を 除く）および上記の各群ごとに病変図の重福きを行 い, 病変の共通範囲を求めた。重ね書きの表現として, 脳の側面図上に， $1 \mathrm{~cm}$ 角ごとに重なった（病変が共通で あった）例数を記した。

\section{IV. 結 果}

1） 20 症例の病巣はすべて左側であった。

2）失語症全例の重ね書きにおいて，重なりが多い 一一側面図上に記した数字が大きい一一のは，脳の側面 図の中央からやや下に寄った部分である。これは前頭葉 後下部，頭頂葉下半部，および側頭葉上半部に相当する (図 1 ).

3） III群については, 前頭葉後下部に病巣をもつもの が多かった（図 2 ).

4） I 群十書字障害については, III群とほぼ同じ重な りを示した（図 3 ).

5）伝導失語群については，前の 2 群に比べて重なり の中心が後上方に片寄り, 頭頂葉の前下部と, 側頭葉の 前上部にわたっていた（図 4 ）.

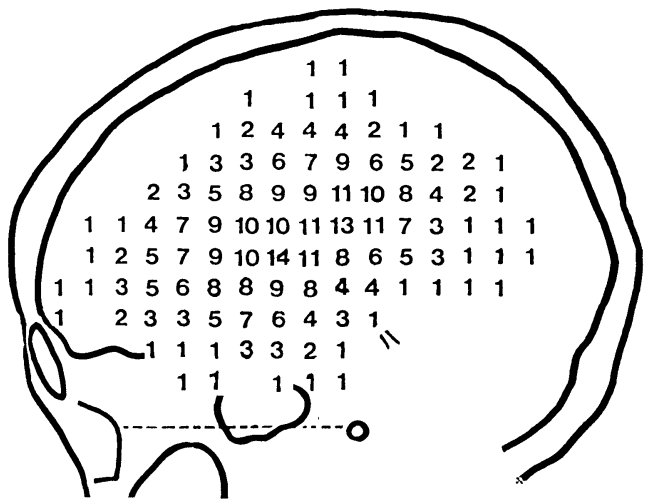

図 1 全失語症例 


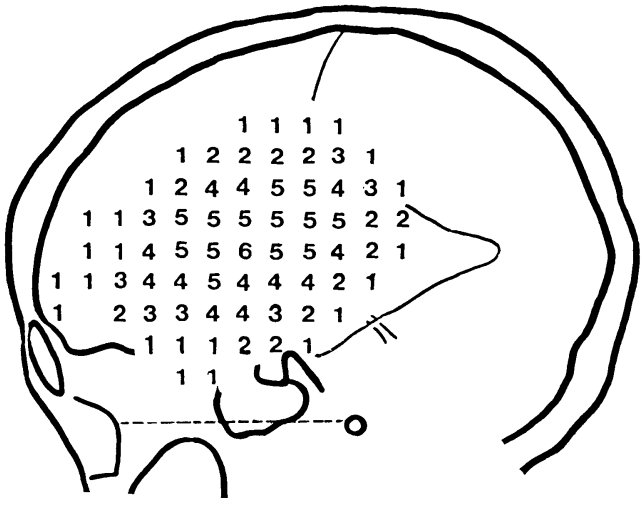

図 2 III群

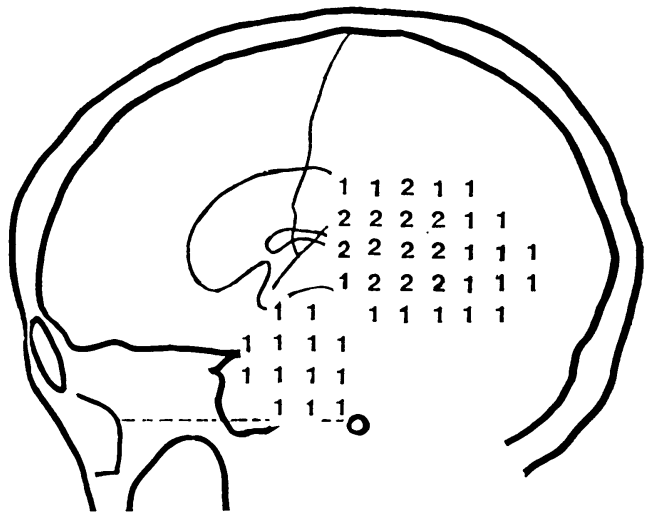

図 .3I I 群十畫字障害

6）右㾁痺, 非失語症の対照群については，2例は上 記の重なりの外にあり，2 例はほぼ同じ範囲に重なって いた（図 5 ).

\section{$\mathrm{V}$. 考按}

頭部外傷や脳血管障害による言語機能衰失 例の 記 録 は，古代にまでさかのぼることができる．大脳の機能局 在論と結びつけて解釈された最初の例は, 1861年に $\mathrm{Br}$ oca の報告した 2 例の失語症である。この 2 例は臨床お よび言語症状と解剖所見が併せて報告されている。言葉 を聴いた場合の了解は良いが，発話が不完全な状態であ ったので aphémie と名づけられた。この報告に基づい て発話の中枢は大脸の左側第三前頭回の脚部にあるとい われるよらになり，この部分は Broca 中权といわれる ようになった。

その後 Wernieke が1874年に, 言語の了解が悪いが, 発話能力が比較的良く保たれている症例について発表 し，左側第一側頭回の後部が言語の聴覚中枢であると報 告した、また，聴覚中枢と発語中枢との間を連絡する線

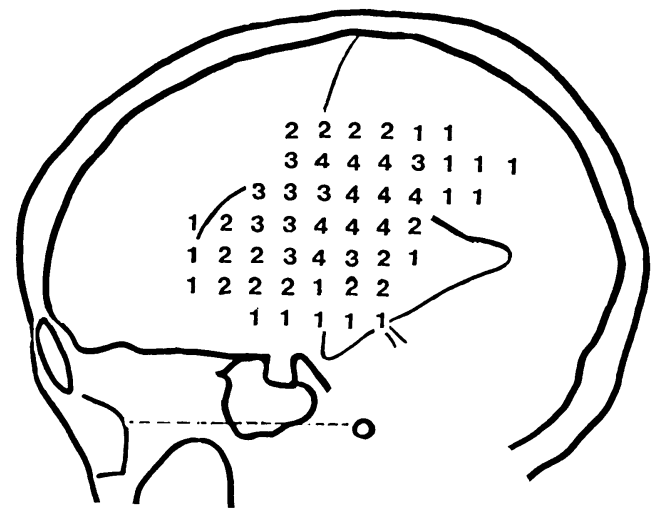

図 4 伝導失語群

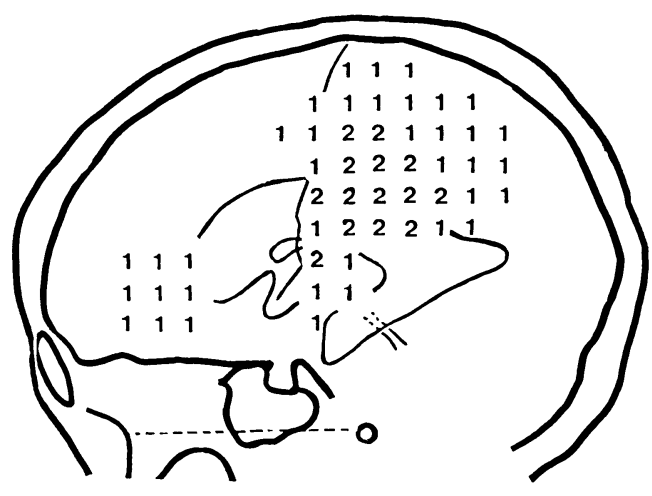

図5 非失語群

維結合が断たれると，鍇語を主症状とする復唱障害が起 こるだろらと考え，伝導失語の存在を推定した。

Broca, Wernieke などのいわゆる古典論の時代にお いては, いくつかの言語中枢と，これらの間の線維結合 を想定してこれを図式化し，その図をもとにして仮説的 な失語症状群を想定し，これを実際の脳障害と言語症状 に対比する方向の研究が多かった．しかし，その後の時 代には大脳全体を一つの機能単位として考えて, 脳障害 における症状と部位との対応は追究しない理論が展開さ れるようになった。 その結果, 現れた症状の臨床心理学 的検討の結果から, 症例を分類する傾向が強くなった.

数多くの研究のらちでソ連の Luria の分類は言語学 的な知見をとり入れて症例を分類するとともに，解剖学 的所見も参考にしている点で興味が深い（Luria ${ }^{4)}$ は cortical analyzer terminals と呼ばれる独立した皮質部 分が視覚, 聴覚, 運動覚, 運動刺激などの分析や統合に あつかっており, 複雑なシステムを構成していると考え ている.そして，失語症状はこれらの analyzer に直接 または間接に障害を生じて起こるものとした。もし，こ 
れらの大脳皮質領域に一つの限局した病巣が生じると, それによって機能的な関連をもつさまざまな系統に障害 が生ずる.これらの障害の組み合わせはそれぞれ特徵的 なパターンを示すので，それによっていろいろな型の障 害が分類できると述べている．失語症にこの考えをあて はめると, Wernieke 中枢の病巣は音素を弁別する障害 を主体とする sensory aphasia をもたらし, 発語, 語 栄, 書字の諸機能を侵す。また左半球の後中心回下部の 病巣は, 言語音レベルの構音障害を主体とする afferent motor aphasiaをもたらし，さらにまた左前頭葉脚部 (Broca 中枢) の病栄は個々の音から音への移行が困難 となる efferent motor aphasia をもたらす. 左前頭葉 障害では自発語の低下や言語の統御機能の低下を示す dynamic aphasia を, 左側頭葉の病巣からは語健忘が前 景に出た acoustic amnestic aphasia がもたらされると 考えた。

一方, 米国の言語病理学者のなかには, 言語の 4 つの 様式, すなわち，聞く，読む，話す，書くとは関係な く，言語の特徵から型分類をする試みがなされるように なった。たとえば Benson ${ }^{5}$ は話す速さ，プロソディー， 語の選択などの 8 つの特徴について段階評価を行い, そ の合計点の分布によって失語症を 2 群に分け，それぞれ A群（non-fluent, 非流暢）とB群 (fluent, 流暢) とし た.この non-fluent は従来の Broea 失語, fluent は Wernicke 失語, 健忘失語, 伝導失語をさしている。こ の 2 群について放射性同位元素を用いたシンチグラムで 脳病変の所在を調べると, A 群では前頭葉後部に病巣が ありまたB群では側頭葉，または頭頂葉に病変がある ことがわかった。このよらに機能上は左側大脳半球を前 半と後半に分けられるので，これらを anterior aphasia そposterior aphasia と呼ぶこともある.

CT-scan による検査は, 失語症の原因となっている 脳病変の探索には, シンチグラムよりもより適した才法 といえよう。ただし，その適用は病巣の榆郭の明らかな ものに限られる. 頭部外傷, 脳の黄縮, 脳手術後遺症に は必ずしも適当でない。また脳血管障書でも新鮮症例に ついては異常所見の範囲と機能脱落との相互関係が明ら かでない、したがって今回の集計には $1 \sim 2$ の例外はあ るが，主として古い脸血管障害患者を対象にした。それ でもなお多発性, または散発性の病変によるもの, 脳萎 縮や脳室払大の著明なものは除外した。そこで本研究の 結果は「失語症の病態像を把握したもの」とはいいがた く, 言語に関する中枢部位を探索するのに適当な症例を 選んだにすぎない。

一般に脳の病巢と, 機能の脱落との関係を考える場合 に, 病巣の全体が脱落した機能を営んでいるとは考えに
くい，脳は皮質（灰白質）と髄質（白質）とからなり， 高度の中枢作用には皮質が特に重要と考えられる。しか し髄質もまた，神経活動の伝達路として無視することは できない。また脳の機能は障害をうけた場合に臨床症状 として容易に把握できるものと, 臨床的知見として捉え 得ないものがあろら. 失語症についてもそのある側面, たとえば「発話の流暢さ」に注目した場合, 発話の流暢 さを欠く症例の病巣範囲のすべてが「発話の流暢さ」に 関係があるのではなく, 病巣の一部がこの機能を担当し ていると考えるべきであろう。

同じ種類の症状をもつ症例の病栄範囲を脳の側面図に ついて重ね書きをし，重なりの多い範囲を探索したの は, 重なりの多い範囲がその症状と密接な関係のある, いわゆる責任部位であると考えたためである。

集計した20例の失語症例の病変部分の重なりから, 次 の知見が引き出されたが，それを順次検討してみたい。

まず全失語症例の病変の重なりは大脳の下半分に多 く, 上半分に少ない. 頭頂葉, 後頭葉に侵襲が及んでい る症例はあるが，これらの部分は言語機能に関する直接 の責任部分とは考㒵にくい. 病変の重なりは前頭葉後下 部に特に濃いことが目立つ。この部分はまた亚群（非流 暢群）に特に著明な重なりがあるので, 運動性の言語機 能に深く関係していると推定される．この範囲は古来い われている Broca 中枢よりも, やや範囲が広い。ただ し, 右片麻痺, 非失語例の 4 例のうち 2 例までも前頭葉 後下部に病巣がみられたことはやや意外である.運動性 言語中枢 (Broca 中枢) の一般性については, なお検討 すべき余地があるといえよう。

伝導失語といわれる特異な病像を示す症例について は, 従来 Wernieke 中枢と Broca 中枢との中間に病巣 があり，その両者間の伝導路が断たれたための症状であ るといわれてきたが，本集計においても，側頭葉の前上 方に病像の著明な重なりが見られ，注目に优する知見で あった。

言語機能の面, すなわら, 聴覚的理解と書字機能につ いては，I群十書字障害として集計したが，特定の部位 との関連を見出することができなかった。これは該当症 例の少ないためであるかもしれない。

上述の研究結果から，CT-scan による断層像が失語 症の診断としても有意義であることがわかった．しかし なお多くの検討すべき余地を残している。

まず, CT 像で軟化巣として写し出される病巣は, 脳 組織の崩壊があって, 機能が停止していることについて は疑いがない。しかしその周辺にはグリアの増殖による 洀痕層があると思われるので，脳としての機能停止の範 囲は軟化巣よりも若干広いと考兄られる。その範囲につ 
いては判断する材料がない。

また病巣は白質まで及んでおり，伝導路も大幅に含ま れていると考えられる．このことは CT-scan で知り得 る軟化巣よりも，さらに広範囲の神経機能に異常がある 可能性を考えさせよう.

本研究では大脳の側面図に病巣像を投影した図を中心 に考察した。したがって脳の左右軸について，すなわ ち, 病栄の深さについては考慮が払われていない.今回 の症例数では無理であったとしても，将来は当然左右軸 を考虑した三次元的な観察が必要である.

今後は失語症検査法も規準化が行われるであろらし， また CT-scan 装置も次第に普及していくであろう。そ れぞれの施設で治療される失語症患者の言語病理学的検 查と C T像が多数例集積され, 複雑な言語症状を理解す る基礎資料が作られることを望みたい。

\section{VI. 結 論}

失語症患者20例の病巣部位を CT-scan で撮影し, 断 層像を集計して次の結論が得られた。

1. 失語症患者の病巣の範囲は, 古来いわれてきた Broca, Wernieke 中枢を含み，その両者をつなぐ範囲に ほぼ相当する.

2 . 発話の非流暢の群は, 左前頭葉の後下部が侵され たものが多い.

3. 伝導失語では, Broca, Wernieke の両中枢の中 間が侵されたものが多い。

4.言語症状と病巣部位との詳細な対比には,さらに 多数の症例の集積が必要である.
本研究の実施にあたっては, 東京都老人総合研究所笹沼澄子 博士のご指導を得た。また, 虎の門病院脳神経外科, 神経内科 各医師，放射線部竹部技師のご協力を得た。併せてお礼を申し 上げる．本論文の要旨は昭和51年度日本音声言語医学会総会で 発表した。

\section{文献}

CT 関係

1) Hausfield, G.N. ; Computerized transverse axial scanning (tomography). ; Part I Description of system. Brit. J. Radiol., 46 : 1016-1022, 1973.

2) Ambrose, J. : Computerized transverse axial scanning (tomography). ; Part II Clinical application. Brit. J. Radiol., 46 : 1023-1047, 1973.

3 ) Schoultz,T.W. et al. : Atlas of the human brain for use in diagnosis by computer assisted tomography. Surg. Neurol., 5 : 255-266, 1976.

失語症関係

4) Luria, A. R. : Higher cortical functions in man. Basic Books, N.Y., 1966.

5 ) Benson, D. F. : Fluensy in aphasia ; correlation with radioactive scan localization. Cortex, $3: 373-$ 394, 1967.

6 ）䇠沼澄子, 永江和久訳 : 成人の失語症(原書 : H.M. Schuell, et al ; Aphasia in Adults-Diagnosis, Prognosis and Treatment). 医学書院, 1971. 